Check for updates

Cite this: RSC Adv., 2017, 7, 51907

Received 26th May 2017

Accepted 31st October 2017

DOI: 10.1039/c7ra05921c

rsc.li/rsc-advances

\section{Comment on "Lewis acidic ionic liquids of crown ether complex cations: preparation and applications in organic reactions" by $Y$. Liang, J. Wang, C. Cheng and H. Jing, RSC Adv., 2016, 6, 93546}

\author{
Małgorzata Swadźba-Kwaśny (ID
}

\section{Introduction}

A paper published recently in RSC Advances reports on a new group of solvate ionic liquids, ${ }^{1}$ generated by the combination of a crown ether (18-crown-6), an alkali metal chloride $(\mathrm{NaCl}$ or $\mathrm{KCl}$ ) and a halide-abstracting agent, which was also a metal chloride $\left(\mathrm{AlCl}_{3}, \mathrm{FeCl}_{3}\right.$, or $\left.\mathrm{ZnCl}_{2}\right){ }^{2}$ The structures of synthesised solvate ionic liquids were postulated (Fig. 1, left). The anion structure was confirmed using Raman spectroscopy, with bands characteristic of $\mathrm{M}-\mathrm{Cl}$ stretching frequencies reported, as shown in Fig. 1, right.

The assignment of bands in spectrum A to $\left[\mathrm{AlCl}_{4}\right]^{-}$and in spectra $\mathrm{B}$ and $\mathrm{D}$ to $\left[\mathrm{FeCl}_{4}\right]^{-}$is consistent with all literature reports, ${ }^{3}$ and supported with appropriate citations. However, assignment of the band at $287 \mathrm{~cm}^{-1}$ (spectra C and E) to $\left[\mathrm{ZnCl}_{3}\right]^{-}$is in stark contrast with the current knowledge.

Anionic speciation in chlorometallate ionic liquids has vital impact on their properties: viscosity of ionic liquids with doubly-charged anions is dramatically higher, conductivity is lower, and chemical behaviour differs, therefore it is of utmost importance to have them correctly understood.

\section{Speciation of chlorozincate anions in ionic liquids - Raman spectroscopy and other techniques vs. mass spectrometry}

The most common chlorozincate anion is $\left[\mathrm{ZnCl}_{4}\right]^{2-}{ }^{4}$ In the Cambridge Structural Database, there is a plethora of deposited single crystal structures with discrete tetrachlorozincate anions - the search for $\left\{\mathrm{ZnCl}_{4}\right\}$ motif returns 849 hits, most of these featuring $\left[\mathrm{ZnCl}_{4}\right]^{2-}{ }^{5}$ In contrast, not a single structure with (presumably) trigonal planar $\left[\mathrm{ZnCl}_{3}\right]^{-}$has been deposited to

QUILL Research Centre, School of Chemistry and Chemical Engineering, Queen's University Belfast, UK. E-mail: m.swadzba-kwasny@qub.ac.uk date. In reference books on vibrational spectroscopy, there is no mention of the $\left[\mathrm{ZnCl}_{3}\right]^{-}$anion, but vibrational frequencies for $\left[\mathrm{ZnCl}_{4}\right]^{2-}$ are always reported - even in Nakamoto's book from $1963\left(\nu_{1}\right.$ frequency at $\left.282 \mathrm{~cm}^{-1}\right) .^{6}$

Nevertheless, in publications on ionic liquids two opposing speciations are proposed: one assuming the existence of $\left[\mathrm{ZnCl}_{3}\right]^{-}$and $\left[\mathrm{Zn}_{2} \mathrm{Cl}_{5}\right]^{-}$anions, ${ }^{7,8}$ and another suggesting the formation of $\left[\mathrm{ZnCl}_{4}\right]^{2-}$ and $\left[\mathrm{Zn}_{2} \mathrm{Cl}_{6}\right]^{2-} .{ }^{9}$ In 2011 we encountered this discrepancy in scientific literature, and decided to address it, as a part of our research on speciation studies of halometallate ionic liquids., ${ }^{3,10-14}$

A multi-technique, multi-phase study on chlorozincate(II) ionic liquids with 1-octyl-3-methylimidazolium, $\left[\mathrm{C}_{8} \mathrm{mim}\right]^{+}$and 1-ethyl-3-methylimidazolium, $\left[\mathrm{C}_{2} \mathrm{mim}\right]^{+}$, cations was carried out. $^{15}$

In order to study the crystalline phase, single crystals were grown from the $\left[\mathrm{C}_{2} \mathrm{mim}\right] \mathrm{Cl}-\mathrm{ZnCl}_{2}$ system at varying stoichiometries (defined in terms of molar fractions of $\mathrm{ZnCl}_{2}, \chi_{\mathrm{ZnCl}_{2}}$ ). The resulting structures were $\left[\mathrm{C}_{2} \mathrm{mim}\right]_{2}\left[\mathrm{ZnCl}_{4}\right]$ for $\chi_{\mathrm{ZnCl}_{2}}=0.33$, and $\left[\mathrm{C}_{2} \mathrm{mim}\right]_{2}\left[\mathrm{Zn}_{2} \mathrm{Cl}_{6}\right]$ for $\chi_{\mathrm{ZnCl}_{2}}=0.50$. Tricoordinate chlorozincate anions were not observed - neither in our study, nor in any other crystallographic work (as per CSD search). ${ }^{5}$ Raman vibrations assigned to the $\mathrm{Zn}-\mathrm{Cl}$ vibrations in these solids were $280 \mathrm{~cm}^{-1}$ for $\left[\mathrm{ZnCl}_{4}\right]^{2-}$, and 264 and $317 \mathrm{~cm}^{-1}$ for $\left[\mathrm{Zn}_{2} \mathrm{Cl}_{6}\right]^{2-}$.

In Raman spectroscopic study of the liquid $\left[\mathrm{C}_{8} \mathrm{mim}\right] \mathrm{Cl}-\mathrm{ZnCl}_{2}$ system, corresponding species were detected, with the $275 \mathrm{~cm}^{-1}$ band for $\left[\mathrm{ZnCl}_{4}\right]^{2-}$ at $\chi_{\mathrm{ZnCl}_{2}}=0.33$, as well as 269 and $312 \mathrm{~cm}^{-1}$ bands for $\left[\mathrm{Zn}_{2} \mathrm{Cl}_{6}\right]^{2-}$ at $\chi_{\mathrm{ZnCl}_{2}}=0.50$. Thus, the presence of $\left[\mathrm{ZnCl}_{4}\right]^{2-}$ and $\left[\mathrm{Zn}_{2} \mathrm{Cl}_{6}\right]^{2-}$ anions was confirmed in both liquid and solid chlorozincate(II) ionic liquids.

Physico-chemical properties of the $\left[\mathrm{C}_{8} \mathrm{mim}\right] \mathrm{Cl}-\mathrm{ZnCl}_{2}$ system were also studied. Particularly telling was the study of Lewis acidity (Gutmann acceptor number approach, using triethylphosphine oxide as the ${ }^{31} \mathrm{P}$ NMR spectroscopic probe). The most significant increase in Lewis acidity was noted at $\chi_{\mathrm{ZnCl}_{2}}=$ 0.33 , that is when $\left[\mathrm{ZnCl}_{4}\right]^{2-}$ ions start being replaced by $\left[\mathrm{Zn}_{2} \mathrm{Cl}_{6}\right]^{2-}$ ions (Fig. 2). Simply based on stoichiometry, such 


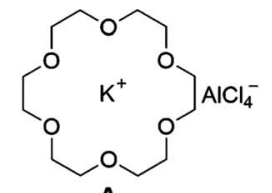

A

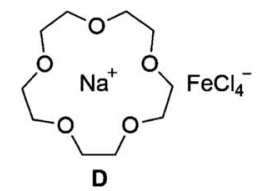<smiles>[Y]C(Cl)(Cl)COCCOCCOCCOCCOCCOCCOCCC(Cl)(Cl)Cl</smiles>

B

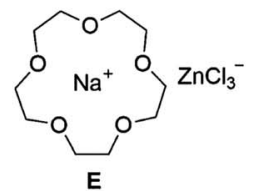

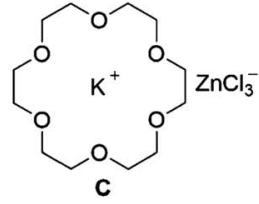

c

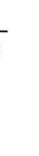

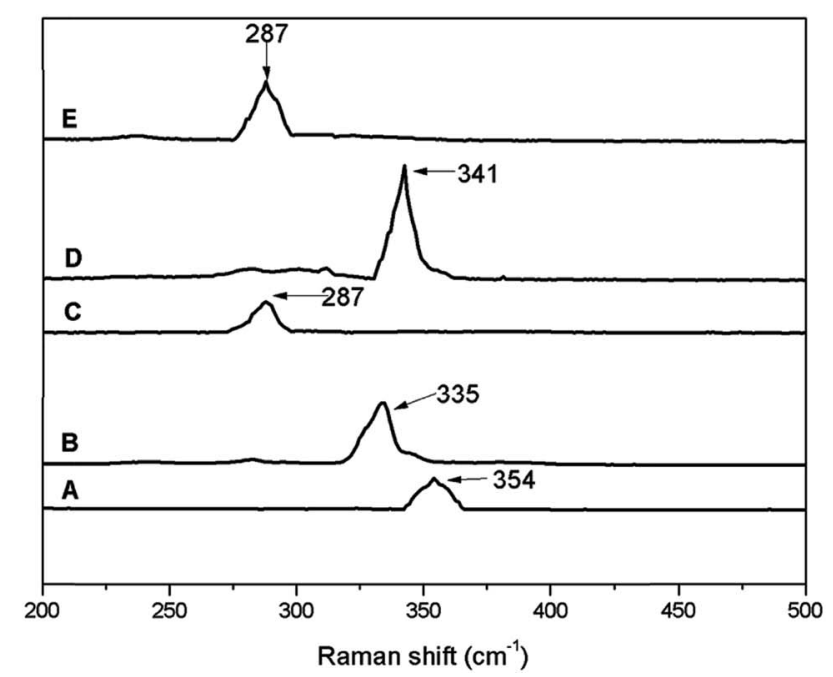

Fig. 1 Left: postulated structures of Lewis acidic ionic liquids; right: fragments of Raman spectra, corresponding to $\mathrm{M}-\mathrm{Cl}$ stretching frequencies. Adapted from ref. 2.

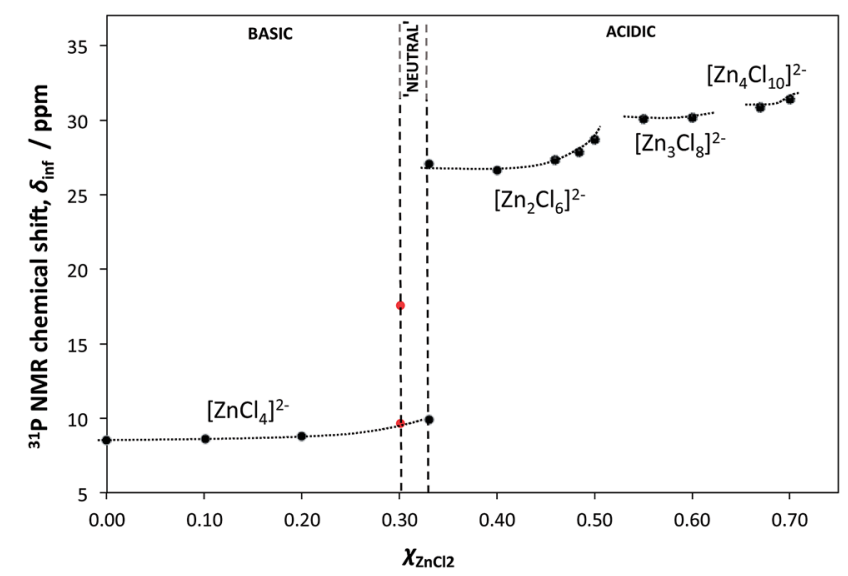

Fig. 2 Plot of the ${ }^{31} \mathrm{P}$ NMR shifts of triethylphosphine oxide (spectroscopic probe of Lewis acidity) dissolved in various compositions of the $\left[\mathrm{C}_{8}\right.$ mim $] \mathrm{Cl}-\mathrm{ZnCl}_{2}$ system, and extrapolated to infinite dilution, $\delta_{\text {inf }}$, as a function of composition $\left(\chi_{\mathrm{ZnCl}_{2}}\right)$. The dotted lines are only visual guides. Adapted from ref. 15.

pattern does not agree with the $\left[\mathrm{ZnCl}_{3}\right]^{-} /\left[\mathrm{Zn}_{2} \mathrm{Cl}_{5}\right]^{-}$speciation, for which there would be no discontinuity in properties at $\chi_{\mathrm{ZnCl}_{2}}$ $=0.33$.

\section{Doubly-charged speciation was also inferred from the pseudo-phase diagram, generated from glass transition in the $\left[\mathrm{C}_{8} \mathrm{mim}\right] \mathrm{Cl}-\mathrm{ZnCl}_{2}$ system}

Finally, ESI-MS spectra of several $\left[\mathrm{C}_{8} \mathrm{mim}\right] \mathrm{Cl}-\mathrm{ZnCl}_{2}$ samples were recorded - and, in contrast to all other multiple techniques, suggested the presence of $\left[\mathrm{ZnCl}_{3}\right]^{-}$and $\left[\mathrm{Zn}_{2} \mathrm{Cl}_{5}\right]^{-}$.
In the literature, although ESI-MS was successfully used to study speciation in a wide variety of compounds, including some complex ionic liquids, e.g. polyiodides, ${ }^{\mathbf{1 6}}$ numerous pitfalls are also reported. Notable are in-depth studies on perturbations in MS by Di Marco and co-workers, ${ }^{17,18}$ and a recent work by Clark and co-workers, entitled "Failure of ESI Spectra to Represent Metal-Complex Solution Composition: A Study of Lanthanide-Carboxylate Complexes". ${ }^{19}$ The likely source of these discrepancies lays the fact that ions detected in MS are in fact in the gas phase, not in the liquid. The mechanisms leading to the formation of gas-phase ions from liquidphase droplets are discussed expertly by Kebarle,$^{\mathbf{2 0 - 2 2}}$ with a recent tutorial review by Awad et al. offering a simple summary on the introductory level. ${ }^{23}$

In our chlorozincate study, under the ESI-MS conditions, the electrostatic factors most likely encouraged the separation of the doubly-negative charge in $\left[\mathrm{Zn}_{2} \mathrm{Cl}_{6}\right]^{2-}$ into two singly-charged $\left[\mathrm{ZnCl}_{3}\right]^{-}$anions. ${ }^{15}$ Identical conclusions were reached in earlier work by Alves et al., published in Journal of Raman Spectroscopy, who stated "there is no experimental result that supports the formation of $\left[\mathrm{ZnCl}_{3}\right]^{-}$or $\left[\mathrm{Zn}_{2} \mathrm{Cl}_{5}\right]^{-}$species, but there are enough experimental data on the formation of $\left[\mathrm{ZnCl}_{4}\right]^{2-}$ and $\left[\mathrm{Zn}_{2} \mathrm{Cl}_{6}\right]^{2-}$ species in $\mathrm{ZnCl}_{2} / \mathrm{LiCl}$ melts (...). Therefore, we interpret the detection of $\left[\mathrm{ZnCl}_{3}\right]^{-}$species by EMS as the result of the reaction $\left[\mathrm{ZnCl}_{4}\right]^{2-} \rightarrow\left[\mathrm{ZnCl}_{3}\right]^{-}+\mathrm{Cl}^{-,} .{ }^{9}$ They also report the $\left[\mathrm{ZnCl}_{4}\right]^{2-}$ anion vibration at $276 \mathrm{~cm}^{-1}$, and list older studies on $\left[\mathrm{ZnCl}_{4}\right]^{2-}$ in various environments, with analogous vibrations at 275,286 and $288 \mathrm{~cm}^{-1}$.

Subsequent investigations were carried out by the licence group using XPS ${ }^{24}$ and by the Abbott group using EXAFS. ${ }^{25}$ Both were consistent with the presence of $\left[\mathrm{ZnCl}_{4}\right]^{2-}$ and $\left[\mathrm{Zn}_{2} \mathrm{Cl}_{6}\right]^{2-}$ species.

Despite this breadth of work, Liang et al. assigned the Raman band at $287 \mathrm{~cm}^{-1}$ to $\left[\mathrm{ZnCl}_{3}\right]^{-}$, citing neither of the above-mentioned articles, but a 1999 paper on aqueous chemistry of zinc chloride, published in Desalination, where the 
existence of such anion is indeed suggested, but with no further literature ref. 26.

\section{Conclusion}

Independent work carried out by several groups, using a very wide range of direct and indirect techniques, demonstrates explicitly two facts: (1) vibrational frequency at $287 \mathrm{~cm}^{-1}$ is in good agreement with a band corresponding to $\left[\mathrm{ZnCl}_{4}\right]^{2-}$, and should be reported as such, and (2) the presence of $\left[\mathrm{ZnCl}_{3}\right]^{-}$in chlorozincate(II) ionic liquids, albeit often cited, may be traced back to mass spectrometry studies, which return results contradictive to: Raman spectroscopy, XPS, EXAFS, and physicochemical properties of chlorozincate(II) ionic liquids.

\section{Conflicts of interest}

There are no conflicts to declare.

\section{Acknowledgements}

I would like to thank Prof. Michael D. Ward for his very constructive remarks that contributed to the clarity of this manuscript.

\section{References}

1 T. Mandai, K. Yoshida, K. Ueno, K. Dokko and M. Watanabe, Phys. Chem. Chem. Phys., 2014, 16, 8761.

2 Y. Liang, J. Wang, C. Cheng and H. Jing, RSC Adv., 2016, 6, 93546.

3 J. Estager, J. D. Holbrey and M. Swadźba-Kwaśny, Chem. Soc. Rev., 2014, 43, 847.

4 J. Burgess and R. H. Prince, Zinc: Inorganic \& Coordination Chemistry, John Wiley \& Sons, Ltd, Chichester, UK, 31st edn, 2006, vol. 7.

5 C. R. Groom, I. J. Bruno, M. P. Lightfoot and S. C. Ward, Acta Crystallogr., Sect. B: Struct. Sci., Cryst. Eng. Mater., 2016, B72, 171.

6 A. Getsis, S. Tang and A.-V. Mudring, Eur. J. Inorg. Chem., 2010, 2010, 2172.

7 V. Lecocq, A. Graille, C. C. Santini, A. Baudouin, Y. Chauvin, J.-M. Basset, L. Arzel, D. Bouchu and B. Fenet, New J. Chem., 2005, 29, 700 .
8 A. P. Abbott, G. Capper, D. L. Davies and R. Rasheed, Inorg. Chem., 2004, 43, 3447.

9 M. B. Alves, V. C. D. Soares, P. A. Z. Suarez and J. C. Rubim, J. Raman Spectrosc., 2008, 39, 1388.

10 D. C. Apperley, C. Hardacre, P. Licence, R. W. Murphy, N. V. Plechkova, K. R. Seddon, G. Srinivasan, M. SwadźbaKwaśny and I. J. Villar-Garcia, Dalton Trans., 2010, 39, 8679.

11 C. Hardacre, R. W. Murphy, K. R. Seddon, G. Srinivasan and M. Swadźba-Kwaśny, Aust. J. Chem., 2010, 63, 845.

12 J. Estager, A. A. Oliferenko, K. R. Seddon and M. SwadźbaKwaśny, Dalton Trans., 2010, 39, 11375.

13 M. Currie, J. Estager, P. Licence, S. Men, P. Nockemann, K. R. Seddon, M. Swadźba-Kwaśny and C. Terrade, Inorg. Chem., 2013, 52, 1710.

14 F. Coleman, G. Feng, R. W. Murphy, P. Nockemann, K. R. Seddon and M. Swadźba-Kwaśny, Dalton Trans., 2013, 42, 5025.

15 J. Estager, P. Nockemann, K. R. Seddon, M. Swadźba-Kwaśny and S. Tyrrell, Inorg. Chem., 2011, 50, 5258.

16 M. Groessl, Z. Fei, P. J. Dyson, S. A. Katsyuba, K. L. Vikse and J. S. McIndoe, Inorg. Chem., 2011, 50, 9728.

17 V. B. Di Marco, G. G. Bombi, S. Zambon and P. Traldi, J. Mass Spectrom., 2009, 44, 120.

18 V. B. Di Marco, L. Raveane, A. Dean and P. Traldi, Rapid Commun. Mass Spectrom., 2010, 24, 868.

19 L. W. McDonald IV, J. A. Campbell and S. B. Clark, Anal. Chem., 2014, 86, 1023.

20 P. Kebarle and L. Tang, Anal. Chem., 1993, 65, 972.

21 P. Kebarle and U. H. Verkerk, Mass Spectrom. Rev., 2009, 28, 898.

22 P. Kebarle, J. Mass Spectrom., 2000, 35, 804.

23 H. Awad, M. M. Khamis and A. El-Aneed, Appl. Spectrosc. Rev., 2014, 50, 158.

24 A. W. Taylor, S. Men, C. J. Clarke and P. Licence, RSC Adv., 2013, 3, 9436.

25 A. P. Abbott, J. C. Barron, G. Frisch, S. Gurman, K. S. Ryder and A. Fernando Silva, Phys. Chem. Chem. Phys., 2011, 13, 10224.

26 F. Aouad, A. Lindheimer, M. Chaouki and C. Gavach, Desalination, 1999, 121, 13. 